\title{
Impact of the Transradial Approach on the Development of Major Bleeding in Elderly Patients Undergoing Percutaneous Coronary Intervention
}

\author{
Pedro Beraldo de Andrade ${ }^{1}$, Marden André Tebet ${ }^{1}$, Mônica Vieira Athanazio de Andrade ${ }^{1}$, \\ Robson Alves Barbosa ${ }^{1}$, Luiz Alberto Mattos ${ }^{1,2}$, André Labrunie ${ }^{1,3}$
}

\begin{abstract}
Background: The development of major bleeding after percutaneous coronary intervention (PCl) is associated with higher morbidity and mortality, and advanced age is one of its main predictors. This analysis aimed to evaluate the impact of the use of the transradial approach on the incidence of bleeding complications in elderly patients undergoing $\mathrm{PCI}$. Methods: This was a consecutive and controlled registry of patients $\geq 60$ years of age undergoing $\mathrm{PCl}$ by the transradial approach. Angiographic procedure success, technical failure, and the incidence of ischaemic adverse events and major bleeding were evaluated. Results: Between May of 2008 and December of 2010, 707 elderly patients underwent PCl; in 635 patients $(89.8 \%)$, the transradial approach was used. The mean age was $69.9 \pm 7.2$ years, and $11.5 \%$ were $>80$ years of age. $39.7 \%$ of the patients female, and $30.9 \%$ had diabetes mellitus. Acute ischaemic syndrome accounted for $72 \%$ of the clinical indications. The angiographic success rate was $96.8 \%$, with a crossover rate of $2.8 \%$. The in-hospital mortality rate was $2.4 \%$ : myocardial infarction occurred in $0.9 \%$, stroke occurred in $0.3 \%$, and stent thrombosis occurred in $0.9 \%$. Hematomas were reported in $1.6 \%$ of the procedures, with a major bleeding rate of $0.8 \%$. Conclusions: In elderly patients undergoing $\mathrm{PCl}$, representative of contemporary practice and with high risk of bleeding, the use of the transradial approach, was associated with a low major bleeding rate.
\end{abstract}

DESCRIPTORS: Angioplasty. Stents. Radial artery. Elderly. Haemorrhage.
RESUMO

Impacto da Utilização do Acesso Radial na Ocorrência de Sangramento Grave entre Idosos Submetidos a Intervenção Coronária Percutânea

Introdução: A ocorrência de sangramento grave após intervenção coronária percutânea (ICP) sabidamente associa-se a maior morbidade e mortalidade, sendo a idade avançada um de seus principais preditores. O objetivo da presente análise foi avaliar o impacto da utilização do acesso radial na incidência de complicações hemorrágicas entre idosos submetidos a ICP. Métodos: Registro consecutivo, controlado, envolvendo pacientes com idade $\geq 60$ anos submetidos a ICP pelo acesso radial. Avaliou-se o sucesso angiográfico do procedimento, a falência da técnica, e a taxa de eventos adversos isquêmicos e de sangramento grave. Resultados: Entre maio de 2008 e dezembro de 2010, 707 pacientes idosos foram submetidos a ICP, dos quais $635(89,8 \%)$ por meio de acesso radial. A média de idade foi de $69,9 \pm 7,2$ anos, $11,5 \%$ tinham idade $>80$ anos, $39,7 \%$ eram do sexo feminino e $30,9 \%$, portadores de diabetes melito. Síndrome isquêmica aguda respondeu por $72 \%$ das indicações clínicas. A taxa de sucesso angiográfico foi de $96,8 \%$, sendo necessária a troca da via de acesso em 2,8\% dos casos. A mortalidade hospitalar situou-se em 2,4\%, infarto agudo do miocárdio em 0,9\%, acidente vascular encefálico em $0,3 \%$ e trombose do stent em $0,9 \%$. Hematomas foram reportados em $1,6 \%$ dos procedimentos, sendo de $0,8 \%$ a taxa de sangramento grave. Conclusões: Entre pacientes idosos submetidos a ICP, representativos da prática contemporânea e de elevado risco para sangramento, o uso do acesso radial associou-se a baixa incidência de sangramento grave.

DESCRITORES: Angioplastia. Stents. Artéria radial. Idoso. Hemorragia.

\footnotetext{
Irmandade da Santa Casa de Misericórdia de Marília - Marília, SP, Brazil.

${ }^{2}$ Instituto Dante Pazzanese de Cardiologia - São Paulo, SP, Brazil.

${ }^{3}$ Hospital do Coração de Londrina - Londrina, PR, Brazil.

Correspondence to: Pedro Beraldo de Andrade. Avenida Vicente Ferreira, 828 - Marília, SP, Brazil - CEP 17515-900

E-mail: pedroberaldo@gmail.com

Received on: 12/6/2011 • Accepted on: 2/15/2012
}

$\mathrm{T}$ he development of severe bleeding after percutaneous coronary intervention $(\mathrm{PCl})$, especially in the context of acute coronary syndrome (ACS), is independently associated with a higher risk of mortality and adverse ischaemic events. ${ }^{1}$

Advanced age is an important predisposing risk factor for severe bleeding due to the greater incidence 
of coexisting diffuse vascular disease, vessel injury, and clinical comorbidities. ${ }^{2,3}$ Additionally, vascular complications related to arterial access represent an important site of bleeding among patients undergoing invasive coronary procedures.

In a systematic review and meta-analysis of randomised studies, the radial approach reduced the prevalence of severe bleeding in $73 \%$ of patients compared to the femoral approach in diagnostic and therapeutic coronary procedures $(0.05 \%$ vs. $2.3 \%$; $P<0.001)$, with a tendency towards reduction in the rates of death, acute myocardial infarction (AMI), and stroke. ${ }^{4}$

The objective of the present study was to evaluate the impact of using the radial approach on the incidence of haemorrhagic complications among elderly patients undergoing $\mathrm{PCl}$, as well as the feasibility of this approach and its efficacy in preventing ischaemic events.

\section{METHODS}

Consecutive patients $\geq 60$ years of age undergoing $\mathrm{PCl}$ using the radial approach were included in a prospective registry of efficacy and safety. The efficacy outcomes were the effective procedure, with residual diameter stenosis percentage of the target lesion $<20 \%$ associated with final TIMI III flow, no need to change the approach (technical failure); and rates of in-hospital mortality, reinfarction, stroke, emergency cardiac surgery, and stent thrombosis. Total procedure duration and fluoroscopy time were recorded from the beginning of the arterial puncture until the removal of the introducer. Safety was evaluated in terms of the occurrence of severe bleeding and vascular complications related to the puncture site. Two pre-specified subgroups were included in the meta-analysis, comparing males and females, and elderly aged 60 to 74 and $\geq 75$ years.

According to the classification of the Bleeding Academic Research Consortium, ${ }^{5}$ severe bleeding was defined as type 3 ( $3 \mathrm{a}$, bleeding with a drop in hemoglobin $\geq 3 \mathrm{~g} / \mathrm{dL}$ and $<5 \mathrm{~g} / \mathrm{dL}$ or transfusion of PRBC; $3 \mathrm{~b}$, bleeding with a drop in hemoglobin $\geq 5 \mathrm{~g} / \mathrm{dL}$, cardiac tamponade, bleeding requiring surgical intervention, or bleeding requiring intravenous vasoactive drugs; 3c, intracranial bleeding or subcategories confirmed by autopsy, imaging exam, lumbar puncture, or intraocular bleeding that hinders vision) or type 5 (5a, probable fatal bleeding; 5b, definitive fatal bleeding). Hematomas were graded according to the classification of the Early Discharge after Transradial Stenting of Coronary Arteries (EASY) study: type I, $\geq 5 \mathrm{~cm}$ in diameter; type II, $\geq 10 \mathrm{~cm}$ in diameter; type III, $>10 \mathrm{~cm}$ in diameter without reaching the elbow; type IV, hematoma extending beyond the elbow; and type $\mathrm{V}$, any hematoma with ischaemic injury to the hand. ${ }^{6}$ Other complications related to the puncture site included arteriovenous fistula, pseudoaneurysm, asymptomatic arterial occlusion, need for surgical vascular repair, and local infection.
After hyperextending the wrist and infiltrating 1-2 mL of $2 \%$ xylocaine, the radial artery was punctured $1 \mathrm{~cm}$ proximal to the styloid process of the radius, using a needle with a 20-22 gauge Jelco polyethylene catheter, and applying the Seldinger technique. After the puncture, a 0.021 guidewire was introduced, followed by a small cutaneous incision with a No. 11 scalpel blade, and a 5-7 F short introducer $(<11 \mathrm{~cm})$ was inserted. A solution containing 5,000 IU of heparin sulphate and $10 \mathrm{mg}$ of isosorbide mononitrate was administered through the extension of the introducer. At the end of the procedure, the introducer was immediately removed, and a compressive dressing with a porous adhesive elastic bandage (TR Band ${ }^{\mathrm{TM}}$, Terumo Medical - Tokyo, Japan) was applied. At the time of hospital discharge, the site of the puncture was subjected to a clinical exam, and the radial pulse was evaluated.

Categorical variables were expressed in terms of frequency and percentage and compared by the chisquared test. Continuous variables were expressed as mean and standard deviation, and compared by either Student's $t$-test or Fisher's exact test. Results with $\mathrm{P}<0.05$ were considered statistically significant. The Statistical Package for Social Sciences (SPSS), version 12.0 (SPSS Inc. - Chicago, IL, USA) was used.

\section{RESULTS}

Between May of 2008 and December of 2010, 1,126 PCls were performed, 707 (62.8\%) of which were performed in patients aged $\geq 60$ years. The radial approach was used in $635(89.8 \%)$ cases, which constituted the analysed sample. The ulnar approach was used in 36 cases $(5.1 \%)$, the femoral approach was used in 35 $(5 \%)$, and the brachial approach was used in one $(0.1 \%)$.

Table 1 presents the demographic characteristics of the patients. The mean age was $69.9 \pm 7.2$ years (60-99); 166 patients $(26.1 \%)$ were $\geq 75$ years, and $11.5 \%$ were $>80$ years. Table 2 shows the characteristics of the procedures. The most common indication was ACS, which was responsible for 458 (72.1\%) cases. Of those, $319(50.2 \%)$ cases were classified as either unstable angina or AMI without ST-segment elevation; $139(21.9 \%)$ cases were classified as AMI with ST-segment elevation, and underwent primary $\mathrm{PCl}$.

The failure rate with use of the radial approach or need to change the approach to complete the procedure was $2.8 \%$. The most common causes of technical failure, in decreasing order, included the following: occlusion of the right brachial artery after previous coronariography using the Sones technique (five cases); excessive tortuosity of the radial artery after its emergence from the brachial artery, which hindered catheter or guidewire progression (three cases); hypoplastic radial artery or spasm during puncture or cannulation attempts (three cases); inadequate support for $\mathrm{PCl}$ (three cases); perforation of a branch of the brachial artery by the 
TABLE 1

\section{Basic Clinical Characteristics}

\begin{tabular}{|c|c|}
\hline Variables & $n=635$ \\
\hline Female gender, n (\%) & $252(39.7)$ \\
\hline Mean age, years & $69.9 \pm 7.2$ \\
\hline Age, $\geq 75$ years, $n(\%)$ & $166(26.1)$ \\
\hline Body mass index, kg/m² & $26.7 \pm 4.6$ \\
\hline Hypertension, n (\%) & $527(83)$ \\
\hline Diabetes mellitus, n (\%) & $196(30.9)$ \\
\hline On insulin & $24(3.8)$ \\
\hline Dyslipidemia, n (\%) & $304(47.9)$ \\
\hline Smoking, n (\%) & $150(23.6)$ \\
\hline $\begin{array}{l}\text { Prior acute myocardial } \\
\text { infarction, } \mathrm{n}(\%)\end{array}$ & $82(12.9)$ \\
\hline $\begin{array}{l}\text { Prior percutaneous coronary } \\
\text { intervention, } \mathrm{n}(\%)\end{array}$ & $71(11.2)$ \\
\hline $\begin{array}{l}\text { Prior myocardial } \\
\text { revascularisation n (\%) }\end{array}$ & $41(6.5)$ \\
\hline Prior stroke, n (\%) & $20(3.2)$ \\
\hline \multicolumn{2}{|l|}{ Indication, n (\%) } \\
\hline Unstable angina/silent ischemia & $177(27.9)$ \\
\hline $\begin{array}{l}\text { Acute myocardial infarction without } \\
\text { ST-segment elevation }\end{array}$ & $319(50.2)$ \\
\hline $\begin{array}{l}\text { Acute myocardial infarction with } \\
\text { ST-segment elevation }\end{array}$ & $139(21.9)$ \\
\hline
\end{tabular}

guidewire (two cases); occlusion of the brachiocephalic artery (one case); and puncture failure in a patient in cardiogenic shock (one case).

Angiographic success was achieved in 615 (96.8\%) PCls. Table 3 presents the hospital outcomes of efficacy and safety. Severe bleeding was recorded in five $(0.8 \%)$ patients and was classified as type 3 ( $3 \mathrm{a}$ in three patients and $3 \mathrm{c}$ in two patients). Hematomas were observed in $1.6 \%$ of the cases, with a predominance of type II.

Regarding the comparative subanalysis between the male and female elderly patients, both groups presented similar demographic characteristics, except for the prevalence of smoking (26.9\% vs. $18.7 \%$; $\mathrm{P}=0.017)$ and prior myocardial revascularisation surgery $(8.1 \%$ vs. $3.6 \%$; $\mathrm{P}=0.029)$ in male patients, and hypertension $(87.7 \% \mathrm{vs}$. $79.9 \%$; $P=0.013)$ in female patients. The total duration of the procedure $(38 \pm 19$ minutes vs. $39 \pm 21$ minutes), fluoroscopy time $(10 \pm 8$ minutes vs. $10 \pm 7$ minutes), and rate of technical failure $(2.1 \%$ vs. $3.9 \%)$ presented no significant difference between the groups. The rates of adverse cardiac events $(3.2 \%$ vs. $1.6 \% ; \mathrm{P}=0.27)$ and
TABLE 2

Characteristics of Percutaneous Coronary Interventions

\begin{tabular}{lc}
\hline Variables & $\mathbf{n}=\mathbf{6 3 5}$ \\
\hline $\begin{array}{l}\text { Elective percutaneous coronary } \\
\text { intervention }\end{array}$ & $355(55.9)$ \\
Ad hoc percutaneous coronary & $141(22.2)$ \\
intervention & \\
Primary percutaneous coronary & $139(21.9)$ \\
intervention & \\
Right radial approach, $\mathrm{n}(\%)$ & $599(94.3)$ \\
Vascular access crossing & $18(2.8)$ \\
rate, $\mathrm{n}(\%)$ & \\
Catheter diameter $6 \mathrm{~F}, \mathrm{n}(\%)$ & $1.9 \pm 1$ \\
Number of catheters, mean & $39 \pm 20$ \\
Procedure duration, minutes & $11 \pm 8.5)$ \\
Fluoroscopy duration, minutes & $284(44.7)$ \\
Uniarterial coronariopathy, $\mathrm{n}(\%)$ & $243(38.3)$ \\
Biarterial coronariopathy, $\mathrm{n}(\%)$ & $108(17)$ \\
Triarterial coronariopathy, $\mathrm{n}(\%)$ & $1.2 \pm 0.5$ \\
Number of stents per patient, mean & $62(9.7)$ \\
Bare-metal stents, $\mathrm{n}(\%)$ & $573(90.3)$ \\
Drug-eluting stents, $\mathrm{n}(\%)$ & $176(27.7)$ \\
Sedation, $\mathrm{n}$ (\%) & $615(96.8)$ \\
\hline Angiographic success, $\mathrm{n}(\%)$ & \\
\hline $\mathrm{n}=$ number of patients. & \\
\hline
\end{tabular}

TABLE 3

In-Hospital Efficacy and Safety Outcomes

\begin{tabular}{lc}
\hline Variables & $\mathbf{n}=\mathbf{6 3 5}$ \\
\hline In-hospital mortality, n (\%) & $15(2.4)$ \\
Acute myocardial infarction, n (\%) & $6(0.9)$ \\
Stroke, n (\%) & $2(0.3)$ \\
Acute and subacute thrombosis, n (\%) & $6(0.9)$ \\
Urgent myocardial & $1(0.2)$ \\
revascularisation, n (\%) & \\
Severe bleeding, n (\%) & $5(0.8)$ \\
Hematoma at the puncture site, n (\%) & $10(1.6)$ \\
Type I hematoma & 2 \\
Type II hematoma & 5 \\
Type III hematoma & 2 \\
Type IV hematoma & 1 \\
Pseudoaneurysm, n (\%) & $1(0.2)$ \\
\hline
\end{tabular}


severe bleeding $(1.6 \%$ vs. $0.5 \% ; P=0.22)$ were higher among women (Figure 1).

Differences regarding demographic characteristics were not observed between patients who were aged 60 to 74 years or $\geq 75$ years (very elderly) except for a higher prevalence of dyslipidemias (51\% vs. 39.2\%; P = 0.011) and smokers $(28.6 \%$ vs. $9.6 \% ; \mathrm{P}<0.0001)$ in the former group. $\mathrm{PCl}$ secundary to ACS was more common in very elderly patients $(78.3 \%$ vs. $69.9 \% ; P=0.044)$. No significant difference was observed regarding the total procedure duration $(38 \pm 21 \mathrm{~min}$ vs. $40 \pm 18 \mathrm{~min})$, fluoroscopy time $(10 \pm 8 \mathrm{~min}$ vs. $11 \pm 7 \mathrm{~min})$, rate of technical failure $(2.3 \%$ vs. $4.2 \%)$, adverse cardiac event rate $(2.3 \%$ vs. $1.8 \% ; \mathrm{P}>0.99)$ or severe bleeding rate $(0.9 \%$ vs. $1.2 \% ; \mathrm{P}=0.65)$ (Figure 2$)$.

\section{DISCUSSION}

Severe bleeding is an important predictor of mortality and of early and late adverse ischaemic outcomes. ${ }^{7}$ The in-hospital mortality and one-year follow-up rates of patients with ACS who develop haemorrhagic complications has been shown to increase by two- to tenfold. ${ }^{8,9}$ In the Global Registry of Acute Coronary Events (GRACE), the most common types of bleeding occur in the gastrointestinal tract $(31.5 \%)$ or are related to the vascular access site $(23.8 \%)$; these are the most prevalent types among patients undergoing invasive procedures. ${ }^{2}$ Although the real prognostic significance of the prevention of complications related to the vascular access site can be questioned, its occurrence is associated with lower adherence by the patient to anti-platelet therapy after hospital discharge, and this is an important and known predictor of recurrent ischaemic complications. ${ }^{10}$ Therefore, actions targeted at reducing vascular complications, such as the use of the radial approach instead of the femoral, have been frequently evaluated and encouraged.

In discussing the main predictors of severe bleeding, advanced age should be mentioned. ${ }^{11}$ Elderly patients are a growing segment of the population, and they commonly undergo invasive coronary procedures. ${ }^{12,13}$

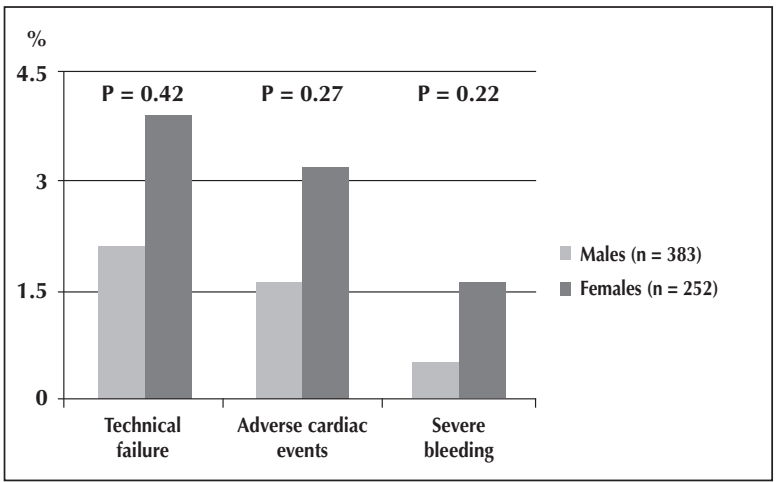

Figure 1 - Efficacy and safety outcomes in male and female elderly patients.
However, the presence of systemic atherosclerosis, pronounced calcification, and vessel tortuosity can limit the success of these procedures and the benefit to the patient due to the inherent difficulties associated with such characteristics. Comparative studies between the radial and femoral approaches in the elderly have shown that the former is associated with longer procedure duration, greater number of catheters used, greater volume of contrast agent required and technical failure. ${ }^{14,15}$ Nonetheless, the radial approach presents a similar success rate, allows for early ambulation, and significantly reduces vascular complications.

In this cohort, in spite of the mean age of 70 years and the predominance of procedures with ACS, which included $22 \%$ of the primary $\mathrm{PCls}$, a high rate of angiographic success and a low prevalence of complications were observed. In this study, the need to change approaches occurred in less than $3 \%$ of the cases and no excessive durations or increased material usage were observed, which reflects the importance of experience and familiarity with the procedure to the final results. ${ }^{16-18}$ Similar findings were reported in a recent subanalysis of the Harmonizing Outcomes with Revascularization and Stents (HORIZONS-AMI) study, in which, compared to the femoral approach, the radial approach was associated with lower rates of severe bleeding, reinfarction, and 30-day and 1-year mortality, with similar procedure durations, fluoroscopy times, and door-balloon times. ${ }^{19}$

Therefore, the radial technique represents a complementary strategy to reduce haemorrhagic complications in the elderly when combined with the following: judicious choice of anti-thrombotic therapy using the minimum effective dose and promoting adjustments when needed; administration of medication in the shortest time possible; and the attempt to achieve fine equilibrium between safety and efficacy. ${ }^{20}$ In fact, even among ACS patients treated with drugs known to be associated with reduced bleeding, such as bivaluridin and fondaparinux, the radial approach resulted in an additional reduction in episodes of severe bleeding. ${ }^{21,22}$

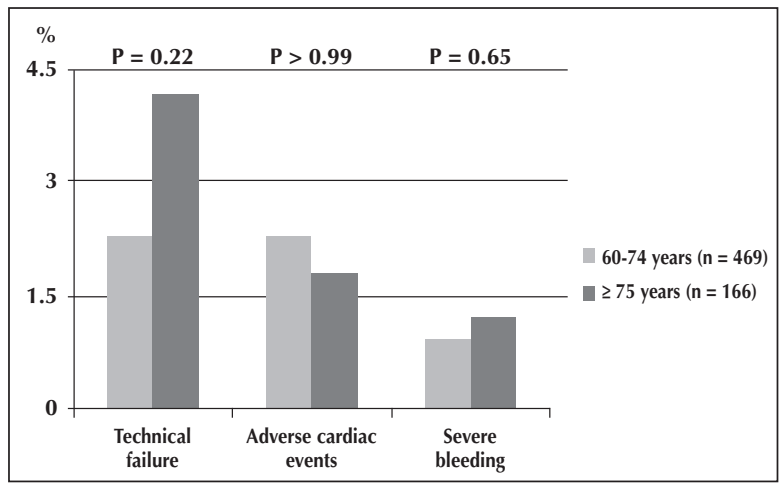

Figure 2 - Efficacy and safety outcomes in elderly patients aged 60 to 74 years and $\geq 75$ years. 


\section{Study limitations}

The limitations of the present study include its observational nature, the absence of a control group composed of patients undergoing PCl through the femoral approach, its performance at a single centre where the radial approach is the main approach used in invasive coronary procedures, and the lack of long-term follow-up.

\section{CONCLUSIONS}

Among elderly patients undergoing $\mathrm{PCl}$, representative of contemporary practice and with high risk for bleeding, the use of the radial approach by physicians familiar with the technique was associated with a low incidence of severe bleeding.

\section{CONFLICTS OF INTEREST}

The authors declare no conflicts of interest.

\section{REFERENCES}

1. Eikelboom JW, Mehta SR, Anand SS, Xie C, Fox KA, Yusuf S. Adverse impact of bleeding on prognosis in patients with acute coronary syndromes. Circulation. 2006;114(8):774-82.

2. Moscucci M, Fox KA, Cannon CP, Klein W, López-Sendón J, Montalescot G, et al. Predictors of major bleeding in acute coronary syndromes: the Global Registry of Acute Coronary Events (GRACE). Eur Heart J. 2003;24(20):1815-23.

3. Kroll RTM, Tanajura LF, Siqueira DAA, Abizaid A, Feres F, Galantini DR, et al. Intervenção coronária percutânea em idosos: impacto da faixa etária mais avançada ( $\geq 80$ anos) no perfil clínico e nos resultados imediatos. Rev Bras Cardiol Invasiva. 2011;19(4):400-4.

4. Jolly SS, Amlani S, Hamon M, Yusuf S, Mehta SR. Radial versus femoral access for coronary angiography or intervention and the impact on major bleeding and ischemic events: a systematic review and meta-analysis of randomized trials. Am Heart J. 2009;157(1):132-40.

5. Mehran R, Rao SV, Bhatt DL, Gibson CM, Caixeta A, Eikelboom J, et al. Standardized bleeding definitions for cardiovascular clinical trials: a consensus report from the Bleeding Academic Research Consortium. Circulation. 2011;123(23):2736-47.

6. Bertrand OF, De Larochellière R, Cabau JR, Proulx G, Gleeton O, Nguyen $\mathrm{CM}$, et al. A randomized study comparing sameday home discharge and abciximab bolus only to overnight hospitalization and abciximab bolus and infusion after transradial coronary stent implantation. Circulation. 2006;114(24):2636-43.

7. Zukowski CN, Costa Junior JR, Costa R, Esteves V, Staico R, Siqueira D, et al. Preditores e impacto clínico intra-hospitalar do sangramento associado à intervenção coronária percutânea. Rev Bras Cardiol Invasiva. 2010;18(3):281-7.

8. Ndrepepa G, Berger PB, Mehilli J, Seyfarth M, Neumann FJ, Schomig A, et al. Periprocedural bleeding and 1-year outcome after percutaneous coronary interventions:appropriateness of including bleeding as a component of a quadruple endpoint. J Am Coll Cardiol. 2008;51(7):690-7.

9. Rao SV, O'Grady K, Pieper KS, Granger CB, Newby LK, Van de Werf F, et al. Impact of bleeding severity on clinical outcomes among patients with acute coronary syndromes. Am J Cardiol. 2005;96(9):1200-6.

10. Roy P, Bonello L, Torguson R, de Labriolle A, Lemesle G, Slottow TL, et al. Impact of nuisance bleeding on clopidogrel compliance in patients undergoing intracoronary drug-eluting stent implantation. Am J Cardiol. 2008;102(12):1614-7.

11. Pocock SJ, Mehran R, Clayton TC, Nikolsky E, Parise H, Fahy M, et al. Prognostic modeling of individual patient risk and mortality impact of ischemic and hemorrhagic complications: assessment from the Acute Catheterization and Urgent Intervention Triage Strategy Trial. Circulation. 2010;121(1):43-51.

12. Thomas Junior NR, Cantarelli MJC, Castello Junior HC, Gioppato S, Gonçalves R, Guimarães JBF, et al. Resultados hospitalares da intervenção coronária percutânea primária no infarto agudo do miocárdio em pacientes com mais de 80 anos. Rev Bras Cardiol Invasiva. 2010;18(1):17-23.

13. Pimentel Filho WA, Carvalho CA, Pelegrini M, Custódio WB Bocchi EA, Soares Neto MM, et al. Intervenção coronária percutânea em pacientes nonagenários. Rev Bras Cardiol Invasiva. 2010;18(1):24-9.

14. Louvard $\mathrm{Y}$, Benamer $\mathrm{H}$, Garot $\mathrm{P}$, Hildick-Smith D, Loubeyre $\mathrm{C}$, Rigattieri $\mathrm{S}$, et al. Comparison of transradial and transfemoral approaches for coronary angiography and angioplasty in octogenarians (the OCTOPLUS study). Am J Cardiol. 2004;94(9):1177-80.

15. Jaffe R, Hong T, Sharieff W, Chisholm RJ, Kutryk MJ, Charron T, et al. Comparison of radial versus femoral approach for percutaneous coronary interventions in octogenarians. Catheter Cardiovasc Interv. 2007;69(6):815-20.

16. Pristipino C, Trani C, Nazzaro MS, Berni A, Patti G, Patrizi R, et al. Major improvement of percutaneous cardiovascular procedures outcomes with radial artery catheterization: results from the PREVAIL study. Heart. 2009;95(6):476-82.

17. Andrade PB, Tebet MA, Andrade MVA, Mattos LA, Labrunie A Segurança e eficácia do acesso radial na realização de procedimentos coronários diagnósticos e terapêuticos em mulheres. Rev Bras Cardiol Invasiva. 2009;17(4):457-62.

18. Andrade PB, Tebet MA, Silva FSM, Andrade MVA, Mattos LA Labrunie A. Utilização do acesso radial elimina a ocorrência de sangramento grave relacionado ao sítio de punção após intervenção coronária percutânea primária. Rev Bras Cardiol Invasiva. 2010;18(4):387-91.

19. Généreux P, Mehran R, Palmerini T, Caixeta A, Kirtane AJ, Lansky AJ, et al. Radial access in patients with ST-segment elevation myocardial infarction undergoing primary angioplasty in acute myocardial infarction: the HORIZONS-AMI trial. Eurolntervention. 2011;7(8):905-16.

20. Steg PG, Huber K, Andreotti F, Arnesen H, Atar D, Badimon L, et al. Bleeding in acute coronary syndromes and percutaneous coronary interventions: position paper by the Working Group on Thrombosis of the European Society of Cardiology. Eur Heart J. 2011;32(14):1854-64.

21. Hamon M, Rasmussen LH, Manoukian SV, Cequier A, Lincoff AM Rupprecht HJ, et al. Choice of arterial access site and outcomes in patients with acute coronary syndromes managed with an early invasive strategy: the ACUITY trial. Eurolntervention. 2009;5(1):115-20.

22. Hamon M, Mehta S, Steg PG, Faxon D, Kerkar P, Rupprecht HJ et al. Impact of transradial and transfemoral coronary in terventions on bleeding and net adverse clinical events in acute coronary syndromes. Eurolntervention. 2011;7(1):91-7. 